\title{
How individuals react to defined benefit pension risk
}

Citation for published version (APA):

Salamanca, N., de Grip, A., \& Sleijpen, O. C. H. M. (2013). How individuals react to defined benefit pension risk. Maastricht University, Graduate School of Business and Economics. GSBE Research Memoranda No. 046 https://doi.org/10.26481/umagsb.2013046

Document status and date:

Published: 01/01/2013

DOI:

10.26481/umagsb.2013046

Document Version:

Publisher's PDF, also known as Version of record

\section{Please check the document version of this publication:}

- A submitted manuscript is the version of the article upon submission and before peer-review. There can be important differences between the submitted version and the official published version of record.

People interested in the research are advised to contact the author for the final version of the publication, or visit the DOI to the publisher's website.

- The final author version and the galley proof are versions of the publication after peer review.

- The final published version features the final layout of the paper including the volume, issue and page numbers.

Link to publication

\footnotetext{
General rights rights.

- You may freely distribute the URL identifying the publication in the public portal. please follow below link for the End User Agreement:

www.umlib.nl/taverne-license

Take down policy

If you believe that this document breaches copyright please contact us at:

repository@maastrichtuniversity.nl

providing details and we will investigate your claim.
}

Copyright and moral rights for the publications made accessible in the public portal are retained by the authors and/or other copyright owners and it is a condition of accessing publications that users recognise and abide by the legal requirements associated with these

- Users may download and print one copy of any publication from the public portal for the purpose of private study or research.

- You may not further distribute the material or use it for any profit-making activity or commercial gain

If the publication is distributed under the terms of Article $25 \mathrm{fa}$ of the Dutch Copyright Act, indicated by the "Taverne" license above, 


\section{Maastricht University}

Nicolás Salamanca,

Andries de Grip, Olaf Sleijpen

How Individuals React to Defined Benefit Pension Risk

$\mathrm{RM} / 13 / 046$

\section{GSBE}

Maastricht University School of Business and Economics

Graduate School of Business and Economics

P.O Box 616

NL- 6200 MD Maastricht

The Netherlands 


\title{
How Individuals React to Defined Benefit Pension Risk
}

\author{
Nicolás Salamanca ${ }^{\mathrm{a},}$, Andries de Grip $^{\mathrm{a}, \mathrm{c}}$, and Olaf Sleijpen ${ }^{\mathrm{b}}$ \\ ${ }^{a}$ Research Centre for Education and the Labour Market (ROA), Maastricht University, The \\ Netherlands \\ ${ }^{\mathrm{b}}$ School of Business and Economics, Maastricht University and De Nederlandsche \\ Bank, The Netherlands \\ ${ }^{\mathrm{c}}$ NETSPAR and IZA
}

This version: August 2013

\begin{abstract}
We develop a measure of (hybrid) defined benefit (DB) pension risk and show how this pension risk affects individual portfolio decisions. We find that people in riskier DB plans are, on average, not only less likely to hold equity but also hold a smaller share of their wealth in equity. This relation is stronger for people who are better informed about their pension plan risk, and for retirees. We also check whether pension risk is related to retirement decisions but find no evidence to support this hypothesis. Our main results are robust to a number of model specifications and alternative explanations. Our findings suggest that properly funded DB pension plans can increase participants' welfare by allowing them to seek higher returns in their individual portfolios while at the same time relieving less sophisticated participants from the decisions required by a defined contribution plan.
\end{abstract}

JEL Codes: D14; G11

Keywords: Individual portfolio; background risk; pension funding; retirement planning

* Corresponding author: tel. +31 4338838 00; fax +31 4338849 14; e-mail n.salamancaacosta@maastrichtuniversity.nl. 


\section{Introduction}

One of the lessons of the current financial crisis is that no one is safe from asset price declines. This is true even for those who do not participate directly in the stock market, since their pension savings may also be exposed to asset price shocks. While the link between asset prices and defined contribution (DC) plans is straightforward, the pensions of defined benefit (DB) plan participants are also exposed to financial risk. DB pension funds also suffer stock market losses and increasingly lay the burden of these losses on their participants through lower indexation, contribution increases, and even cuts in benefits and pension accruals. This is particularly true when the DB plan has evolved from a traditional DB arrangement into a hybrid DB scheme. Such hybrid schemes are currently in place in various countries, such as the Netherlands, Canada, Luxembourg, and Switzerland, and in most of these countries DB and hybrid DB schemes have the largest asset share (OECD Global Pension Statistics for 2011). In the United Kingdom alone more than 7.8 million people save for retirement in DB plans. ${ }^{1}$ Yet, for all its importance, we know little about how individuals respond to the risks in their DB pension savings. Are DB pension plan participants aware of the risk their pension savings bear? And do they react to such risk?

In this paper we develop a time-varying pension-fund-specific measure of (hybrid) DB pension risk from the perspective of the pension plan contributors and beneficiaries and analyze their reactions to variations of such risk. In particular, we analyze how people adjust their individual portfolio allocations to financial equity and their intended retirement age in reaction to changes in their pension risk. Our empirical analysis is based on the pension system of the Netherlands. Dutch retirement plans have three characteristics that provide excellent grounds for answering our research question. First, for the Dutch, DB

\footnotetext{
${ }^{1}$ National Association of Pension Funds (United Kingdom), retrieved June 28, 2013, from http://www.napf.co.uk/PolicyandResearch/Policy_topics/Defined_Benefit_Pensions.aspx.
} 
plans are the main tool for saving for retirement, next to first pillar pensions (stateprovided pay-as-you-go funded pension benefits). The DB nature of these plans implies that any risk taken by the pension fund will not be directly compensated for by higher pensions for the participants, with the exception of foregone benefit indexation. Second, since the dot-com crisis at the beginning of this century, Dutch retirement plans have evolved from traditional DB into hybrid DB plans. Pension benefits are still linked to wages, but the indexation of benefits to inflation is now conditional on the pension fund's financial position and is therefore linked to financial market developments (Ponds and van Riel, 2009). This change has increased the market risk sustained by DB plan participants. Third, employees cannot freely choose the pension fund to which they contribute; each organization or sector has a pre-assigned pension fund for all its employees. This institutional feature makes it impossible for people to switch pension funds if they are dissatisfied with the fund's risk strategy or performance but do not want to move to a job in another firm or sector of industry. Therefore, Dutch workers only have their own asset holdings and retirement age as means to optimize their financial risk exposure. ${ }^{2}$

We use uniquely matched data on pension fund performance from the Dutch National Bank (De Nederlandsche Bank, or DNB) and a representative survey of the individual savings and investments of Dutch households, the DNB Household Survey (DHS). The pension fund's performance data allow us to calculate our measure of pension fund risk, which we match and correlate with a rich set of characteristics and observed behavior at the individual level found in the household survey data.

Consistent with the intuition presented above, our results show that people who face more pension risk are less likely to invest in financial equity. This finding holds for the

\footnotetext{
${ }^{2}$ The hybrid DB and no-choice policy of pension funds in the Netherlands facilitates our analyses, but it does not mean that our results are relevant only for countries where there is no free pension fund choice. Our results apply to any market with DB pensions and pension fund-switching-costs, as long as people recognize or are made aware that their DB pensions carry some risk.
} 
decision to hold equity - the extensive margin — as well as the share of wealth invested in equity - the intensive margin. Also consistent with our behavioral hypothesis, we find that the impact of pension risk is generally strongest for those who are aware of their pension indexation status (and thus more likely to be aware of their DB pension risk), as well as for retirees. We find no conclusive evidence that people adjust their retirement age decision in response to pension risk. We show that these results are robust to several model specifications and modifications of our estimation methodology and present evidence supporting their behavioral validity.

To the best of our knowledge, we are the first to quantify individual portfolio reactions to DB pension fund risk. Most of the current literature on individual pension decisions is focused on whether people are capable of optimal decision making when it comes to saving for retirement, particularly when allocating their DC pension wealth (e.g., individual retirement accounts and 401(k) accounts). Benartzi and Thaler (2001, 2007) show that people are excessively passive when making these investment decisions and often fall prey to naïve diversification strategies when managing their retirement portfolios. Consistent with this evidence, van Rooij et al. (2007) show that the Dutch, if given a choice, would mostly prefer DB over DC schemes to avoid having to make complicated pension-related decisions. These studies, however, have little to say about those in DB plans, where the investment decisions are made for them.

Samwick and Skinner (2004) and Poterba et al. (2007) argue that, in the United States, everyone but the most risk-averse people would prefer DC plans, even though they are riskier and more likely to end up yielding extremely low pensions. Their model assumptions and data, however, do not account for the fact that the lower risk offered by DB plans allows people to take more risk and improve their returns on their own portfolios, which can increase their retirement wealth. Our results show that people are able to 
identify the risk in DB pension funds and hold more equity when their pension risk is low. A good understanding of these phenomena can help in the choice of pension scheme policies and shows the advantages of properly designed hybrid DB schemes that, while financially sustainable, can also greatly increase individual welfare.

We further contribute to the literature on optimal reaction to background risk. Our results can be easily understood in the context of background risk diversification: When people are exposed to background risk on one asset in their portfolio, they adjust by taking on less risk in their other assets. ${ }^{3}$ Heaton and Lucas (2000) calibrate the relation between background risk and individual portfolios. ${ }^{4}$ These authors, among others, tackle the issue of background risk by calibrating optimal individual decisions under different kinds of market frictions and in the presence of tradable and non-tradable risk. By directly observing the decisions of people facing such risks, we make a positive rather than a normative assessment of their reactions. Curcuru et al. (2010) provide direct evidence of the relation between types of background risk and individual portfolio allocations and briefly address pension risk by showing that participation in a DB plan essentially has no relation to stock ownership. However, the authors use only a crude measure of pension risk (contributing to a DC or DB plan) and, since they do not focus on pension-related background risk, pay no further attention to the issue. Guiso et al. (1996) and Rosen and Wu (2004), among others, show that individuals adjust their portfolios in the presence of background risks such as labor and health, but these studies also ignore background risk in pension holdings. Our focus on the financial behavior of people who face measurable DB pension risks and our method of measuring such risks are unique in the field.

\footnotetext{
${ }^{3}$ Our results are also consistent with the framework of risk vulnerability, as introduced by Pratt and Zeckhauser (1987) and Gollier and Pratt (1996). The core idea is that risky assets will be less attractive for people forced to bear an unfair background risk (i.e., with a non-positive expected value and uncorrelated with other assets they hold). To the extent that DB pension risk is similar to an unfair background risk from the perspective of the participants, our results fit this theory.

${ }^{4}$ They also make an extensive review of the literature on background risk and portfolio choice.
} 
The remainder of the paper is structured as follows. Section 2 explains the Dutch pension system and introduces our measure of DB pension risk. Section 3 describes our data and our empirical methodology. Section 4 presents our main results, discusses some heterogeneous effects that support our identification strategy, and describes the various robustness analyses we performed. Section 5 concludes the paper.

\section{DB pension risk and the Dutch pension system}

In the Netherlands all workers are obliged to participate in their employers' occupational pension plans. Moreover, some employers are obliged to participate in pension plans that are shared by entire sectors of industry. As a result, there is a very high participation of workers in Dutch pension funds from an international perspective, and a relatively high replacement ratio (OECD, 2011). The drawback is that employees cannot opt out of their pension fund, even when it is performing poorly.

The capitalization of Dutch occupational pension funds is among the world's highest (146\% of the gross domestic product in 2011, according to DNB statistics). While many countries have witnessed a shift from traditional DB plans to DC plans, this has hardly been the case in the Netherlands. One of the reasons for the success of the Dutch pension system is the willingness of both employers and unions to adjust the traditional DB pension scheme to changing circumstances (Sleijpen, 2009). This practice goes back to the beginning of this century, following the dot-com crisis, which eroded the value of pension fund assets. After this crisis, the indexation of pension benefits to prices or wages became dependent on the financial position of the pension fund. This financial position is measured through the funding ratio, the value of the fund's assets divided by the value of its pension liabilities. ${ }^{5}$

\footnotetext{
${ }^{5}$ The dot-com crisis also resulted in other changes, such as a shift from final-pay schemes to average-wage schemes.
} 
The changes in pension plan conditions, as agreed upon by employers and unions, were implemented in the Pension Law 2007, which changed a number of pension fund regulations. First, it introduced market valuation of assets and liabilities. ${ }^{6}$ Second, it allowed pension benefits to be cut if 1 ) the funding ratio drops below the minimum $105 \%$ required by law $^{7}$ and does not recover after three years and 2) if other recovery measures cannot be resorted to (ultimum remedium) ${ }^{8}$ Third, it determined that each pension fund should hold (solvency) reserves that depend on the riskiness of the pension fund's asset mix. These solvency reserves are a key element of our measure of pension fund risk. However, since they were only introduced in 2007 , we have no way to measure pension risk with our tool before that year.

Solvency reserves, operating through the so-called required funding ratio, are an important element of our measure of pension fund risk. Since 2007, pension funds have been required to hold additional reserves above the so-called minimum required funding ratio designed to cushion potential shocks in the (developed and emerging) equity markets, the real estate market, private equity investments, as well as interest rates fluctuations, credit risk, and exchange rate risk. The size of the solvency reserves required for each fund depends on their own exposure to each of these markets, as well as on the correlations between these shocks. The underlying (standard) solvency model, as laid down in the Pension Law 2007 and used by pension funds to determine their solvency reserves, is calibrated such that the probability of a pension fund being underfunded at a one-year horizon is less than $2.5 \%{ }^{9}$ The required funding ratio is then defined as the funding ratio

\footnotetext{
${ }^{6}$ Since the Pension Law 2007, pension liabilities have been valued by using risk-free market interest rates to reflect their duration. In practice, swap rates are used as a proxy for risk-free interest rates.

${ }^{7}$ Following the IORP Directive (2003/41/EC) of June 3, 2003.

${ }^{8}$ Due to the financial crisis, it was decided in 2008 to temporarily extend this three-year recovery period to five years. Nevertheless, a number of Dutch pension funds have had to reduce their benefits and accruals (DNB, 2013).

${ }^{9}$ The size of the shocks to each asset class and the correlations between these shocks have been calibrated using historical data and the solvency requirements are calculated based on this model in a Value-At-Risk type of analysis. For instance, for equity holdings, pension funds have to assume a shock of $25 \%$ (for developed markets). This means that a pension fund
} 
resulting from the minimum $105 \%$ funding plus the additional solvency requirements. The model directly translates lower risks into lower required reserves, since the required buffer will be smaller. In other words, the lower the riskiness of the pension fund, the lower the required funding ratio will be. In 2006, the underlying standard solvency model was calibrated such that the required funding ratio would be $130 \%$ for the average Dutch pension fund. Toward the end of 2010, the average required funding ratio amounted to approximately $122 \%$ (DNB, 2011), since most pension funds decreased the riskiness of their portfolios.

The contribution and indexation policies of most Dutch pension funds regarding are based on so-called policy ladders (Ponds and van Riel, 2009). Policy ladders describe the deterministic dependency of contribution rates and indexation rates on the funding ratio. A typical indexation policy ladder is shown in Figure 1, where there is no indexation below a funding ratio of $105 \%$ and full indexation above $130 \%$. Typically, full indexation is provided when the funding ratio is at or above the required funding ratio. If the funding ratio is over $100 \%$ in real terms, then indexation that was not previously provided can be restored and contribution rates can be reduced. The latter is legally possible only after prior indexation has been fully restored.

\section{[INSERT FIGURE 1 ABOUT HERE]}

The required funding ratio relative to the actual funding ratio is a good measure of perceived DB pension risk. If the actual funding ratio is greater than the required one, the fund's financial position is comfortable and the full indexation of pension benefits is not in

with an outstanding equity of 100 will have to hold a solvency requirement with respect to equity market risk of 25 . The assumed correlations between shocks usually lead to somewhat lower solvency requirements for equity holdings. More information about the model can be found at http://www.toezicht.dnb.nl/en/2/51-202140.jsp. 
doubt; the pension fund' perceived riskiness is low from the point of view of plan participants. The reverse is true when the required funding ratio is greater than the actual funding ratio. In that case there is no indexation or only partial indexation and even a risk of cutting pension benefits and increasing contributions. In that case, the pension fund's perceived riskiness is high. Since plan members cannot "vote with their feet," they have to resort to other measures to change their risk exposure if their pension fund does not deliver. They can, for instance, change their private pension savings (i.e., in the third pillar of the pension system), but they can also change the asset allocation of their private savings and investments and even adjust their retirement age. ${ }^{10}$ The latter two behavioral responses are the focus of this paper.

\section{Data and methodology}

\subsection{The DHS}

Our main source of data is the DHS, an Internet survey of a representative panel of Dutch households collected by CentERdata since 1993. The DHS currently surveys around 2,000 Dutch households each year. CentERdata provides participating households with an Internet connection, a television, and a set-top box for the television to facilitate survey response. All persons aged 16 and over within each household are invited to take part in the survey. This study uses the 2007 through 2011 waves.

To analyze portfolio decisions, we focus on equity investments. We define equity as the sum of direct stockholdings, mutual funds, and options. The other components of household financial wealth are checking, saving, and deposit accounts; government and municipal

\footnotetext{
${ }^{10}$ This feature does not mean that our analysis is exclusive to the Netherlands. Our results apply to any legislation in which the costs of switching pension funds (either monetary, legal, or in terms of time) are high enough that people would rather reoptimize their individual portfolios and change their planned retirement age than go through the trouble of switching pension funds. Considering the decreasing costs of equity investments and the complexity involved in changing pension funds, rebalancing one's individual portfolios may be the preferred choice for most DB fund participants. Changing the planned retirement age may carry additional psychological costs, though.
} 
bonds; mortgage bonds; illiquid saving certificates; and other unspecified investments and savings. To analyze the decision to hold some equity-the extensive margin in portfolio choice - we create a dummy variable that takes the value of one if a person owns equity and zero otherwise. To analyze the intensive margins in portfolio choice, we use the share of total financial wealth invested in equity (bounded at zero and 100).

To analyze the intended retirement age, we use the answers to the following question: "At what age do you expect to retire, or to make use of the early retirement arrangement?" For the extensive margin in individuals' planned retirement age we create a dummy variable that takes the value of one if a person is planning to retire before the age of 65 and zero otherwise. This has typically been the retirement age in the Netherlands, although in 2007 some disincentives were introduced for the early retirement of specific age cohorts. Our results are the same if we take these changes into account when constructing the early retirement dummy. For the intensive margin in individuals' planned retirement age, we take the expected retirement age of the respondents (bounded at 99 by the answer categories in the survey).

Throughout the analyses we control for education, wealth in durable assets, home ownership, risk preferences, income, age, gender, marital status, household composition, and labor market status. All these variables were taken from the DHS. Summary statistics for all the variables introduced above are presented in Table 1 for the DHS waves of 2007 through 2011 and for our estimation sample. The estimation sample is similar to the DHS sample in most respects but is slightly wealthier and older, which in turn results in an underrepresentation of self-employed and unemployed people and an overrepresentation of married people and retirees. These small selectivity issues are probably due to survey answering behavior uncorrelated with our pension risk measure and are therefore unlikely to cause problems in our analyses. However, in Section 4.2 we show the heterogeneous effects 
for each of these groups so that interested readers can judge for themselves what the likely bias due to sample selectivity might be.

\section{[INSERT TABLE 1 ABOUT HERE]}

\subsection{Pension fund performance data}

We measure the riskiness of each DB pension fund using the relation between their required funding ratio, as decreed by Dutch pension legislation, and their actual funding ratio. To match these data to the DHS, we use a survey question that asks the name of the pension fund to which each person contributes (for employees) or receives benefits from (for retirees). The estimation sample contains 31 different pension funds to which people contribute. We use the names of these pension funds to match the individual survey data with the required and actual funding ratios of each pension fund from 2007 through 2011. From this information we construct our measure of DB pension fund risk, our main regressor, as Pension risk $=\frac{\text { Required funding -actual funding }}{\text { actual funding }}$. High values of this measure indicate the relative strain of the pension fund's financial position and therefore its riskiness.

Figure 2 shows the distribution of pension risk for both the entire sample of individual observations and the sample of pension funds observed in the data. From the figure it is clear that there are marked differences in exposure to pension risk. A large part of the observations fall above zero, meaning that actual funding is less than required. If we look at the changes in the distribution of pension risk over time, we see that in 2007 most funds' actual funding was greater than required, but from 2008 onward this was reversed due to the financial crisis. In 2011, the average actual funding still fell short of the average required funding.

The differences between both distributions in Figure 2 arise because people are not evenly distributed across sample pension funds. Most people in our samples contribute to 
risker funds in our sample. However, this should not cause any problem with our identification strategy, since the distribution of perceived pension risk by individuals (left) maintains the general right-skewed risk distribution of the pension funds' risk in our sample (right). Moreover, there are enough individual observations to identify the effects of pension risk throughout the relevant range of pension risk values.

\section{[INSERT FIGURE 2 ABOUT HERE]}

\subsection{Econometric framework}

Our main analysis is based on four different empirical models - two for the extensive portfolio and retirement age margins and two for their intensive margins. All our models can be described in the simple form

$$
y_{i t}^{*}=\beta_{1} \text { pension risk } k_{i t}+\beta_{2}^{\prime} X_{i t}+\gamma_{j}+\theta_{t}+\varepsilon_{i t}
$$

where $y_{i t}^{*}$ is a latent dependent variable; $X_{i t}$ is a set of controls; $\gamma_{j}$ and $\theta_{t}$ are pension fund and year fixed effects, respectively; $\varepsilon_{i t}$ is assumed to be a zero-mean, normally distributed error term; and our main parameter of interest is $\beta_{1} \cdot{ }^{11}$ For the extensive margins we use probit models to analyze the effect of pension risk on the decision to invest in equity and to retire early. Thus, for these models we observe $y_{i t}=1$ if $y_{i t}^{*}>0$ and zero otherwise. For the intensive margins we use Tobit models to analyze the effect of pension fund risk on individual portfolio shares in equity and on expected retirement age. Thus, for these models we observe $y_{i t}=y_{U}$ if $y_{i t}^{*} \geq y_{U}, y_{i t}=y_{i t}^{*}$ if $y_{U}>y_{i t}^{*}>y_{L}$, and $y_{i t}=y_{L}$ if $y_{i t}^{*} \leq y_{L}$. The Tobit models account for censoring at zero and 100 for the equity share (which occurs naturally) and right censoring at 99 for expected retirement age (which was imposed by the

\footnotetext{
${ }^{11}$ There are no advantages to modeling the portfolio decisions and retirement age plans jointly. A bivariate probit model that allows the error term to be correlated across equations yields virtually identical coefficient estimates. The model cannot reject the null that $\rho$, the correlation coefficient between error terms, is zero.
} 
survey). To facilitate the interpretation of our results, all the tables below report average marginal effects, which, for conciseness, we refer to as effects throughout Section 4, without any claim to their causality.

In every regression the controls, $X_{i t}$, include wealth (in the form of the log of wealth in durable assets and a dummy for home ownership), income, age, education, gender, and family composition. These controls are common in the literature on portfolio choice (e.g., Rosen and Wu, 2004; Hong et al., 2005; Guiso et al., 2008). We also include a measure of willingness to take on financial risk, a key determinant of portfolio choice. We control for differences in labor market status through dummy variables for self-employment, unemployment, and retirement. Note that the presence of $\gamma_{j}$ and $\theta_{t}$ in our analyses means that the effect of pension fund risk is identified solely through within-pension fund variations in pension risk. ${ }^{12}$

The fact that our estimation sample includes the crisis years requires special attention. During the crisis, especially between 2007 and 2008, the funding ratio of all the pension funds in our sample decreased. It is unclear how this common shock could affect the identification of our main results, especially since it is largely accounted for by $\theta_{t}$. However, to show that this should not be an issue for our identification, we show the time evolution of pension risk for each pension fund and the variation used to identify our results in Figure 3. The left panel of Figure 3 shows the significant impact the financial crisis had on pension risk for all pension funds. However, the right panel, which plots the residuals of regressing pension risk by year and pension fund dummies (normalizing the starting point of the series at zero for 2007), shows that even after accounting for common year shocks and discarding between-pension fund variations, there is still substantial movement in our measure of pension risk.

\footnotetext{
${ }^{12}$ Our main results are robust to various alternative specifications, with and without pension fund and year dummies.
} 


\section{[INSERT FIGURE 3 ABOUT HERE]}

A remaining estimation issue is the calculation of our standard errors. Since our main regressor, pension risk, has the same value within a given year and fund for every person, ordinary calculations of the standard errors could suffer from a downward bias (Moulton, 1990). To account for this bias, we use robust standard errors for all the effects reported, clustered at the pension fund level. ${ }^{13}$

\section{Results}

\subsection{Effects of pension fund risk}

Table 2 presents our main results. Column (1) shows that greater pension risk is negatively related to the decision to hold equity. Column (3) further shows that greater pension risk also decreases the share of wealth invested in equity. The interpretation is clear: People who perceive more risk in their pensions have less extensive and intensive investments in equity in their individual portfolios.

The relation between pension fund risk and individual portfolio allocation is economically important. The marginal effects in Table 2 indicate the impact of a pension fund being roughly $1 \%$ more underfunded. To gain some perspective on the economic importance of these effects, note that the standard deviation of pension risk in our estimation sample is about 18.3 points. This means that the economic impact of a one standard deviation increase in pension risk can be estimated as 18.3 times the size of the marginal effects. So, bearing one standard deviation more pension risk causes one to be, on average, 7.3 percentage points less likely to own equity $(0.004 * 18.3)$ and to hold 3.6 percentage

\footnotetext{
${ }^{13}$ The statistical significance of our main results holds if we use a cluster bootstrap t-procedure similar to that of Cameron et al. (2008) on average marginal effects.
} 
points less wealth in equity $(0.198 * 18.3)$. These effects are only slightly smaller than the impact of having a university education versus not finishing high school or of being a homeowner versus renting. To give our findings even more perspective, note that the unconditional chance of owning equity in our sample is only $26 \%$ and that average people hold only about $10.5 \%$ of their wealth in equity.

\section{[INSERT TABLE 2 ABOUT HERE]}

Columns (2) and (4) of Table 2 show that pension risk has no effect on plans for early retirement or on expected retirement age, even though the signs of both effects are consistent with our hypothesis. Although these results are not what we expected, there are some possible explanations. It may simply be that people do not consider their retirement age as a mean to adjust for shocks in wealth variance, even though studies show that people adjust their expected retirement age to shocks in pension wealth related to changes in pension schemes (French, 2005; De Grip et al., 2012). It may also be that, due to psychological costs, changing one's retirement age is more costly for people than adjusting their individual portfolios. Therefore, the entire adjustment to pension risk takes place at the portfolio level. There may also be a "bracketing" explanation: Losses brought on by additional pension risk are evaluated as financial losses and therefore people who suffer such a loss react primarily via financial instruments. Finally, a simpler explanation may be that the effects in the expected retirement equations are less precisely estimated because the expected retirement age is measured with more noise.

Table 2 also shows the effects of other socioeconomic variables on equity investment and expected retirement. Having a university education increases investment in equity, consistent with fixed information and cognitive costs of investment in the stock market. It 
also decreases the likelihood of expecting to retire early, which is consistent with a larger opportunity cost of early retirement for those with substantial human capital investments. Wealth in durable assets and home ownership increases investment in equity and decreases expected retirement, consistent with fixed monetary costs of equity investment, with housing being treated as a risk-free asset. Table 2 also shows that wealthier people with home equity, which can be used to fund their retirement consumption, retire earlier. Willingness to take on financial risk affects portfolio choice in the expected way and has minor effects on expected retirement, suggesting that early retirement is seen as a risky choice. Income has no effect on portfolio choice but is a strong predictor of expected retirement. This finding is consistent with the wealth effects discussed above and again shows that people are more willing to retire early if they are doing well financially.

Age has a positive effect on equity investment. This effect is not due to the limited functional form in which age enters the estimation; we confirm positive age effects in unreported analyses using quadratic and cubic polynomials and non-parametric regressions. This result is at odds with lifecycle portfolio theory studies that predict individuals take on less financial risk as they age (e.g., Bodie et al., 1992). However, several empirical studies also show positive age effects on equity holding and share of wealth in equity (e.g., Donkers and van Soest, 1999; Poterba and Samwich, 2002; Kaustia and Torstila, 2011; van Rooij et al., 2011). Age is also positively related to early retirement expectations. However, this association is due to two relatively large jumps in early retirement expectations - one around the age of 25 and the other around 45-in an otherwise fairly flat age effect distribution. Expected retirement age also evolves rather flatly with age, with a mild upward trend after the age of 50. Furthermore, women plan to retire earlier than men and married people expect to retire earlier than single people. Retirees invest less in equity. 


\subsection{Identification through heterogeneous effects}

We have shown that pension risk has an important effect on individual equity allocations but no effect on expected retirement age. Since all our regressions include both year and pension fund fixed effects, we identify the effect of pension risk using only within-pension fund variations. Moreover, we control for a rich set of characteristics in all regressions. Still, one might wonder whether our measure of pension risk correctly captures what we want it to measure or whether our main effects are just driven by correlated factors that we do not observe. In this section we present various heterogeneous effects of pension fund risk that support the identification of our main results and provide some information on their drivers.

For pension risk to affect behavior, people must be aware that such risk exists. Therefore, we should only expect to observe a change in behavior due to pension risk for people who are aware of their risk. We test this hypothesis using the answers to the following DHS question:

A pension plan can include an arrangement for correcting the pension that can be claimed and/or the pension that is actually being paid according to a price-index and/or to a salary-index. Pensions that are corrected in this way are called indexed to inflation. Is your (future) retirement pension indexed to inflation?

Answering this question with either yes or no suggests that the respondent is acquainted with the indexation conditions of his or her pension fund and therefore more likely to be aware of pension risk. Answering "I don't know" suggests ignorance or disinterest in the topic and therefore unawareness of pension risk. Based on this intuition, we construct a dummy variable for pension risk awareness and calculate the heterogeneous effects of pension risk on this dummy via an interaction term. ${ }^{14}$ The corresponding effects for those

\footnotetext{
${ }^{14}$ About $74 \%$ of our sample was aware of the indexation status of their pension funds. Section 4.3 presents evidence that people's answers to this question are roughly consistent with what their pension fund performance would suggest about the indexation provided.
} 
who are aware their pension risk and those who are not are presented in the top panel of Table 3.

The results show that the mean effect of pension risk on equity investments is mainly driven by those who are aware of their pension risk. The size of the effect for these people is significantly larger than the size of the effect for unaware people. In addition, pension risk only has the expected sign for the expected retirement age equations for those who are aware of their pension risk. These results support the hypothesis that our main results reflect changes in individual behavior due to pension risk.

We can also check the identification of our main results by looking at the behavior of retirees. As mentioned, in the Netherlands the inflation indexation policy of pension benefits is linked to the pension fund's funding. Since pension income is naturally a more important source of income for retirees than for those still in the labor force, retirees should react more sharply to changes in pension fund risk. We test whether this is the case by calculating the effects of pension risk on equity investments for those in the labor force and retirees separately. The results, presented in the second panel of Table 3, show that pension fund risk has a stronger impact on the equity investment decisions of retirees, again supporting a behavioral change triggered by pension risk as the true source of our findings.

\section{[INSERT TABLE 3 ABOUT HERE]}

\subsection{Robustness analyses}

In this section we briefly describe the robustness checks we ran on our main results. Respectively, we tackle (1) the possibility that common stock market shocks affect both pension risk and individual portfolios, (2) the quality of our measure of pension risk 
awareness, (3) the addition of retirement and housing wealth to the model, (4) the issue that pension fund mobility may be possible in spite of high costs, and (5) various other alternative model specifications. All the results in this section are shown in the Appendix. By and large, we conclude from this section that our main results hold.

The first concern we address is the existence of common shocks to pension risk and people's portfolios. In particular, we consider the possibility that a drop in stock prices could both increase pension risk and decrease people's equity holdings (e.g., because people do not rebalance their portfolios that often). We do not think this to be likely, because of two reasons. First, for our main results to be entirely mechanical, we should not observe any effect of pension risk on equity participation. Second, generalized stock market shocks are largely accounted for by $\theta_{t}$. Nevertheless, as an additional check, we include in our regressors each pension fund's portfolio composition (their share of assets invested in equity, fixed income securities, real estate, and other investments). We report our results in Table A1. The effect of pension risk, which is almost identical to that of Table 2, now reflects differences in pension risk that are unrelated to the asset composition of the pension funds. This rules out any common shocks that could affect pension asset composition.

A second concern is that the people who answered the pension indexation question may not know as much about their pension status as they claim. However, as Table A2 shows, when we compare pension risk and actual funding ratios for those who answered yes or no to the question "Is your (future) retirement pension indexed to inflation?" the pension funds of those who answered yes have significantly lower risk and have higher mean and median funding ratios. Moreover, the median funding for those who answered yes is well above the minimum required of $105 \%$, whereas the median funding for those who said no is well 
below. Our data thus suggest that our survey respondents are indeed aware and informed about their pension indexation status and pension risk. ${ }^{15}$

A third concern is that some regressors in our main specification were not given enough attention or were not properly measured. In particular, this may be the case of pension and housing wealth: To the extent that these are correlated with pension risk, excluding them from the model may affect our main results. However, Tables A3 and A4 show that including these two regressors does not substantially change the main effects of pension risk. $^{16}$

A fourth concern is that, even though it is very costly for people to change pension funds, their dissatisfaction with their pension fund performance may be so severe that pushes them to change jobs or enter into self-employment or unemployment. Our data, however, show that this is not likely to be an issue: Table A5 shows that the probability of staying with the same pension fund from one year to the next is quite high, about $83 \%$, and most of the pension fund changes are due to people changing jobs (since transition probability of being employed from one year to the next is about 97\%). Moreover, the table also shows that when people change pension funds, they end up in funds that are, if anything, riskier. In view of this evidence, the hypothesis that labor market mobility may be related to pension risk seems very unlikely.

\footnotetext{
${ }^{15}$ These results are perhaps less surprising in the Netherlands than in other countries. This is because the Dutch people who contribute (or have contributed in the past) to a pension fund receive an overview of their contributions that includes information about the fund's performance. Moreover, the recent pension reform and other pension regulation changes and the fact that pension wealth is quite high in the Netherlands has spurred substantial press coverage of pension-related topics.

${ }^{16}$ Pension wealth is measured through the answer to the following question:

"According to the overview, what will be your gross pension a year from age 65? For working people

who are now connected to [a] pension fund: this refers to the amount you would get at age 65 if you stop working now."

This question is not nearly as odd as it sounds for a Dutch respondent; "pension income if quitting now" is explicitly reported in the pension overview sent to Dutch contributors each year. Housing wealth is measured by the original purchase price of the house as reported in the survey (we obtain similar results if we use the current estimated value of the house or province-year interaction fixed effects). These measures are not included in the main specification because they would have reduced the sample size considerably.
} 
Finally, we tried various alternative model specifications and changes in the estimation method and our results were robust to them all. The results are reported in Table A6.

\section{Conclusions}

In this paper we show that individuals react to DB pension risk by rebalancing their individual portfolios. People who bear more pension risk are often less likely to hold any equity and also hold a lower share of their wealth in equity, on average. These relations are mainly driven by people who are more likely to be aware of their pension risk (i.e., those who reported knowing the indexation policy of their pension funds) and retirees, two groups that should be more affected according to our behavioral hypothesis. We also expected pension risk to be related to intended retirement age, but this hypothesis is not supported by our data.

The recent literature on retirement portfolio choice states that people are ill equipped to make proper decisions about their retirement and have a preference for DB-type plans. Even so, Poterba et al. (2007) argue that DB plans are not the best choice for most people, since DC plans provide better retirement conditions in almost every case. Our results contest this hypothesis. We show that people with DB plans adjust their individual portfolios in reaction to their DB pension risk, which suggests that people are maximizing the risk-return tradeoff in their total portfolio, even though they cannot directly influence their risk exposure through their pension savings. A well-funded DB pension system would therefore allow people to obtain higher returns through their individual portfolios while relieving less sophisticated investors from the portfolio decisions entailed in a DC system. This system improves the welfare of employees and retirees alike, since DB and hybrid DB schemes do relieve some of the participants' risk compared to DC plans. 


\section{Acknowledgments}

We thank Erzo Luttmer, Raymond Montizaan, Joan Muysken, Mukul Tyagi, Maria Zumbühl, and seminar participants at the Dutch National Bank (DNB), the 11th International Workshop on Pension, Insurance \& Saving at Paris Dauphine, and the 2013 Netspar International Pension Workshop for helpful comments and suggestions. We owe special thanks to Albertine Palsma (DNB) for her help in making data available to us. In this paper use is made of data of the DNB Household Survey and relevant data with respect to pension funds. 


\section{References}

Benartzi, Shlomo, and Richard H. Thaler. "Naive diversification strategies in defined contribution saving plans.” American Economic Review (2001), 91(2), pp. 79-98.

Benartzi, Shlomo, and Richard H. Thaler. "Heuristics and biases in retirement savings behavior." Journal of Economic Perspectives (2007), 21(3), pp. 81-104.

Bodie, Zvi, Robert C. Merton, and William F. Samuelson. "Labor supply flexibility and portfolio choice in a life cycle model." Journal of Economic Dynamics and Control (1992), 16(3), pp. 427449 .

Cameron, A. Colin, Jonah B. Gelbach, and Douglas L. Miller. "Bootstrap-based improvements for inference with clustered errors." Review of Economics and Statistics (2008), (90)3, pp. 414-427.

Curcuru, Stephanie, John Heaton, Deborah Lucas, and Damien Moore. "Heterogeneity and portfolio choice: Theory and evidence." In Handbook of Financial Econometrics (2010), Vol. 1, Amsterdam, Elseiver: pp. 337-382.

De Grip, Andries, Maarten Lindeboom, and Raymond Montizaan. "Shattered dreams: The effects of changing the pension system late in the game." Economic Journal (2012), 122(559), pp. 1-25.

De Nederlandsche Bank, "Uitwerking herziening berekeningssystematiek Vereist Eigen Vermogen" [Elaboration of the revised methodology with respect to the Required Own Reserves], DNP publication, June (2011).

De Nederlandsche Bank, “DNB rondt evaluatie herstelplannen af' [DNB finishes evaluation recovery plans], DNB Press Release, April 25 (2013).

Donkers, Bas, and Arthur van Soest. "Subjective measures of household preferences and financial decisions." Journal of Economic Psychology (1999), 20(6), pp. 613-642.

French, Eric. "The effects of health, wealth, and wages on labour supply and retirement behaviour." Review of Economic Studies (2005), 72(2), pp. 395-427.

Gollier, Christian, and John W. Pratt. "Risk vulnerability and the tempering effect of background risk." Econometrica: Journal of the Econometric Society (1996), 64(5), pp. 1109-1123.

Guiso, Luigi, Tullio Jappelli, and Daniele Terlizzese. "Income risk, borrowing constraints, and portfolio choice.” American Economic Review (1996), 86(1), pp. 158-172.

Guiso, Luigi, Paola Sapienza, and Luigi Zingales. "Trusting the stock market." Journal of Finance (2008), 63(6), pp. 2557-2600.

Heaton, John, and Deborah Lucas. "Portfolio choice in the presence of background risk." Economic Journal (2000), 110, pp. 1-26.

Hong, Harrison, Jeffrey D. Kubik, and Jeremy C. Stein. "Social interaction and stock-market participation." Journal of Finance (2004), 59(1), pp. 137-163.

Kaustia, Markku, and Sami Torstila. "Stock market aversion? Political preferences and stock market participation." Journal of Financial Economics (2011), 100, pp. 98-112. 
Moulton, Brent R. "An illustration of a pitfall in estimating the effects of aggregate variables on micro units." Review of Economics and Statistics (1990), 72(2), pp. 334-338.

Organisation for Economic Co-operation and Development, Pensions at a Glance 2011: Retirement Income Systems in OECD and G20 countries, available at www.oecd.org/els/social/pensions/PAG (2011).

Ponds, Eduard H.M., and Bart van Riel. "Sharing risk: The Netherlands' new approach to pensions." Journal of Pension Economics \& Finance (2009), 8(1), pp. 91-105.

Poterba, James, Rauh, Joshua, Venti, Steven, \& Wise, David. "Defined contribution plans, defined benefit plans, and the accumulation of retirement wealth." Journal of Public Economics (2007), 91(10), pp. 2062-2086.

Poterba, James M., and Andrew A. Samwick. "Taxation and household portfolio composition: US evidence from the 1980s and 1990s." Journal of Public Economics (2002), 87(1), pp. 5-38.

Pratt, John W., and Richard J. Zeckhauser. "Proper risk aversion.” Econometrica (1987), 55(1), pp. $143-154$.

Rosen, Harvey S., and Stephen Wu. "Portfolio choice and health status." Journal of Financial Economics (2004), 72(3), pp. 457-484.

Samwick, Andrew A., and Jonathan Skinner. "How will 401(k) pension plans affect retirement income?” American Economic Review (2004), 94(1), pp. 329-343.

Sleijpen, Olaf C.H.M., "Exporteerbaarheid van het Nederlandse pensioenstelsel naar de Europese Unie" [On the exportability of the Dutch pension system to the European Union], Inaugural lecture, February 6, 2009, School of Business and Economics, Maastricht University.

Van Rooij, Maarten C.J., Clemens J.M. Kool, and Henriëtte M. Prast. "Risk-return preferences in the pension domain: Are people able to choose?" Journal of Public Economics (2007), 91(3), pp. $701-722$.

Van Rooij, Maarten, Annamaria Lusardi, and Rob Alessie. "Financial literacy and stock market participation.” Journal of Financial Economics (2011), 101(2), pp. 449-472. 
Table 1: Summary statistics of the main variables for the DHS 2007-2011 observations and the estimation sample

\begin{tabular}{|c|c|c|c|c|c|c|}
\hline & \multicolumn{3}{|c|}{ DHS 2007-2011 } & \multicolumn{3}{|c|}{ Estimation sample } \\
\hline & Obs. & Mean & Std. dev. & Obs. & Mean & Std. dev. \\
\hline Holds equity & 5,779 & 0.21 & 0.41 & 2,958 & 0.26 & 0.44 \\
\hline Equity share of wealth & 5,779 & 8.97 & 22.09 & 2,958 & 10.47 & 22.87 \\
\hline Plans to retire early & 3,151 & 0.32 & 0.47 & 1,817 & 0.45 & 0.50 \\
\hline Expected (early) retirement age & 3,230 & 70.43 & 13.74 & 1,817 & 67.21 & 11.03 \\
\hline Total wealth (1,000 euros) & 7,003 & 51.06 & 153.86 & 2,958 & 63.10 & 148.92 \\
\hline Total durable assets value (1,000 euros) & 6,841 & 16.09 & 88.27 & 2,958 & 17.86 & 65.61 \\
\hline Lives in own house & 15,105 & 0.79 & 0.41 & 2,958 & 0.77 & 0.42 \\
\hline High school degree & 15,054 & 0.39 & 0.49 & 2,958 & 0.33 & 0.47 \\
\hline University or college degree & 15,054 & 0.30 & 0.46 & 2,958 & 0.46 & 0.50 \\
\hline Gross income (1,000 euros) & 5,700 & 27.03 & 24.85 & 2,958 & 35.17 & 20.07 \\
\hline Age & 14,321 & 47.57 & 17.44 & 2,958 & 55.81 & 13.89 \\
\hline Female & 15,105 & 0.53 & 0.50 & 2,958 & 0.39 & 0.49 \\
\hline Married & 15,111 & 0.52 & 0.50 & 2,958 & 0.73 & 0.45 \\
\hline Willingness to take on financial risk & 6,476 & 2.70 & 1.03 & 2,958 & 2.61 & 1.01 \\
\hline Number of people in household & 15,105 & 2.94 & 1.31 & 2,958 & 2.37 & 1.16 \\
\hline Self-employed & 15,105 & 0.06 & 0.24 & 2,958 & 0.01 & 0.09 \\
\hline Unemployed & 15,105 & 0.02 & 0.13 & 2,958 & 0.01 & 0.09 \\
\hline Retired & 15,105 & 0.16 & 0.36 & 2,958 & 0.33 & 0.47 \\
\hline
\end{tabular}


Table 2: Main effects of pension fund risk on household portfolio holdings and planned retirement age

\begin{tabular}{|c|c|c|c|c|}
\hline & \multicolumn{2}{|c|}{ Probit models } & \multicolumn{2}{|c|}{ Tobit models } \\
\hline & (1) & (2) & (3) & (4) \\
\hline Dependent variable $=$ & $\begin{array}{l}\text { Holds } \\
\text { equity }\end{array}$ & $\begin{array}{l}\text { Plans to } \\
\text { retire early }\end{array}$ & $\begin{array}{l}\text { Equity } \\
\text { share }\end{array}$ & $\begin{array}{l}\text { Exp. } \\
\text { retirement } \\
\text { age }\end{array}$ \\
\hline Pension risk & $\begin{array}{c}-0.004 * * \\
(0.002)\end{array}$ & $\begin{array}{l}-0.000 \\
(0.003)\end{array}$ & $\begin{array}{c}-0.198 * * \\
(0.083)\end{array}$ & $\begin{array}{c}0.041 \\
(0.054)\end{array}$ \\
\hline High school degree & $\begin{array}{c}-0.012 \\
(0.037)\end{array}$ & $\begin{array}{c}-0.064 * \\
(0.033)\end{array}$ & $\begin{array}{l}-1.388 \\
(1.553)\end{array}$ & $\begin{array}{c}0.151 \\
(1.222)\end{array}$ \\
\hline University or college degree & $\begin{array}{c}0.081 * * \\
(0.038)\end{array}$ & $\begin{array}{c}-0.092 * * * \\
(0.022)\end{array}$ & $\begin{array}{l}3.131^{*} \\
(1.858)\end{array}$ & $\begin{array}{c}0.287 \\
(0.732)\end{array}$ \\
\hline Log of durable assets & $\begin{array}{c}0.009 * * * \\
(0.002)\end{array}$ & $\begin{array}{c}0.009 * * * \\
(0.003)\end{array}$ & $\begin{array}{c}0.286^{* * *} \\
(0.102)\end{array}$ & $\begin{array}{c}-0.146 * * \\
(0.061)\end{array}$ \\
\hline Lives in own house & $\begin{array}{c}0.095 * * * \\
(0.025)\end{array}$ & $\begin{array}{c}0.114^{* * *} \\
(0.036)\end{array}$ & $\begin{array}{c}4.451 * * * \\
(1.080)\end{array}$ & $\begin{array}{c}-2.615^{* * *} \\
(0.640)\end{array}$ \\
\hline Willingness to take on financial risk & $\begin{array}{c}0.123 * * * \\
(0.010)\end{array}$ & $\begin{array}{l}0.014 * \\
(0.008)\end{array}$ & $\begin{array}{c}5.973 * * * \\
(0.507)\end{array}$ & $\begin{array}{c}-0.190 \\
(0.258)\end{array}$ \\
\hline Log of income & $\begin{array}{c}0.016 \\
(0.010)\end{array}$ & $\begin{array}{c}0.094 * * * \\
(0.019)\end{array}$ & $\begin{array}{c}0.570 \\
(0.459)\end{array}$ & $\begin{array}{c}-3.590 * * * \\
(0.421)\end{array}$ \\
\hline Age & $\begin{array}{c}0.005 * * * \\
(0.001)\end{array}$ & $\begin{array}{c}0.003 * * * \\
(0.001)\end{array}$ & $\begin{array}{c}0.295 * * * \\
(0.046)\end{array}$ & $\begin{array}{c}0.080 * * * \\
(0.025)\end{array}$ \\
\hline Female & $\begin{array}{c}-0.015 \\
(0.010)\end{array}$ & $\begin{array}{c}0.085 * * * \\
(0.033)\end{array}$ & $\begin{array}{c}0.123 \\
(0.493)\end{array}$ & $\begin{array}{c}-0.013 \\
(0.689)\end{array}$ \\
\hline Married & $\begin{array}{c}0.007 \\
(0.026)\end{array}$ & $\begin{array}{c}0.169 * * * \\
(0.022)\end{array}$ & $\begin{array}{l}-0.101 \\
(0.965)\end{array}$ & $\begin{array}{l}-0.639 \\
(0.675)\end{array}$ \\
\hline Number of people in household & $\begin{array}{l}-0.005 \\
(0.007)\end{array}$ & $\begin{array}{c}-0.001 \\
(0.007)\end{array}$ & $\begin{array}{l}-0.228 \\
(0.285)\end{array}$ & $\begin{array}{c}-0.456^{* * *} \\
(0.154)\end{array}$ \\
\hline Self-employed & $\begin{array}{l}-0.162 \\
(0.117)\end{array}$ & $\begin{array}{l}-0.028 \\
(0.128)\end{array}$ & $\begin{array}{l}-7.961 \\
(5.017)\end{array}$ & $\begin{array}{c}0.513 \\
(3.116)\end{array}$ \\
\hline Unemployed & $\begin{array}{c}-0.004 \\
(0.094)\end{array}$ & $\begin{array}{l}-0.082 \\
(0.119)\end{array}$ & $\begin{array}{c}-0.411 \\
(4.433)\end{array}$ & $\begin{array}{c}4.162 \\
(2.851)\end{array}$ \\
\hline Retired & $\begin{array}{c}-0.102 * * * \\
(0.023)\end{array}$ & & $\begin{array}{c}-4.734 * * * \\
(0.996)\end{array}$ & \\
\hline Year fixed effects & Yes & Yes & Yes & Yes \\
\hline Pension fund fixed effects & Yes & Yes & Yes & Yes \\
\hline Observations & 2,958 & 1,811 & 2,958 & 1,817 \\
\hline
\end{tabular}




\section{Table 3: Heterogeneous effects of pension fund risk by retirement status and pension indexation knowledge}

\begin{tabular}{|c|c|c|c|c|}
\hline \multirow{4}{*}{ Dependent variable $=$} & \multicolumn{2}{|c|}{ Probit models } & \multicolumn{2}{|c|}{ Tobit models } \\
\hline & (1) & (2) & (3) & (4) \\
\hline & $\begin{array}{l}\text { Holds } \\
\text { equity }\end{array}$ & $\begin{array}{c}\text { Plans to } \\
\text { retire } \\
\text { early }\end{array}$ & $\begin{array}{c}\text { Equity } \\
\text { share }\end{array}$ & $\begin{array}{l}\text { Exp. } \\
\text { retirement } \\
\text { age }\end{array}$ \\
\hline & & fect of per & sk for peopl & \\
\hline Unaware of pension risk & $\begin{array}{c}-0.003 * \\
(0.002)\end{array}$ & $\begin{array}{c}0.001 \\
(0.002)\end{array}$ & $\begin{array}{c}-0.131 * \\
(0.077)\end{array}$ & $\begin{array}{c}-0.004 \\
(0.050)\end{array}$ \\
\hline Aware of pension risk & $\begin{array}{c}-0.004 * * \\
(0.002)\end{array}$ & $\begin{array}{l}-0.000 \\
(0.003)\end{array}$ & $\begin{array}{c}-0.227 * * * \\
(0.087)\end{array}$ & $\begin{array}{c}0.066 \\
(0.053)\end{array}$ \\
\hline Observations & 2,958 & 1,811 & 2,958 & 1,817 \\
\hline \multirow[t]{4}{*}{ Difference test (p-value) } & 0.032 & 0.251 & 0.006 & 0.003 \\
\hline & $\begin{array}{l}\text { Holds } \\
\text { equity }\end{array}$ & $\begin{array}{c}\text { Plans to } \\
\text { retire } \\
\text { early }\end{array}$ & $\begin{array}{c}\text { Equity } \\
\text { share }\end{array}$ & $\begin{array}{l}\text { Exp. } \\
\text { retirement } \\
\text { age }\end{array}$ \\
\hline & $(1)$ & (3) & $(4)$ & $(6)$ \\
\hline & \multicolumn{4}{|c|}{ Effect of pension risk for: } \\
\hline People still in labor force & $\begin{array}{c}-0.003 * \\
(0.002)\end{array}$ & - & $\begin{array}{c}-0.166^{* *} \\
(0.077)\end{array}$ & - \\
\hline Retirees & $\begin{array}{c}-0.005 * * \\
(0.002)\end{array}$ & - & $\begin{array}{c}-0.287 * * \\
(0.116)\end{array}$ & - \\
\hline Observations & 2,958 & - & 2,958 & - \\
\hline Difference test ( $p$-value) & 0.101 & - & 0.058 & - \\
\hline \multicolumn{5}{|c|}{$\begin{array}{l}\text { Standard errors clustered at the pension fund level are in parentheses. } * * * p<0.01, * * p<0.05, * p< \\
0.1 \text {. The effects of the first panel are derived from probit and Tobit regressions that interact a pension } \\
\text { risk-aware dummy with pension risk. The effects of the second panel are derived from probit and } \\
\text { Tobit regressions that interact a retired dummy with pension risk. Naturally, for the second panel, } \\
\text { Columns (3) and (4) are not estimable. All columns report average marginal effects. All regressions } \\
\text { include the same control variables as reported in Table } 2 \text { and include year and pension fund fixed } \\
\text { effects. }\end{array}$} \\
\hline
\end{tabular}


Figure 1: Typical indexation policy ladder for a Dutch pension fund

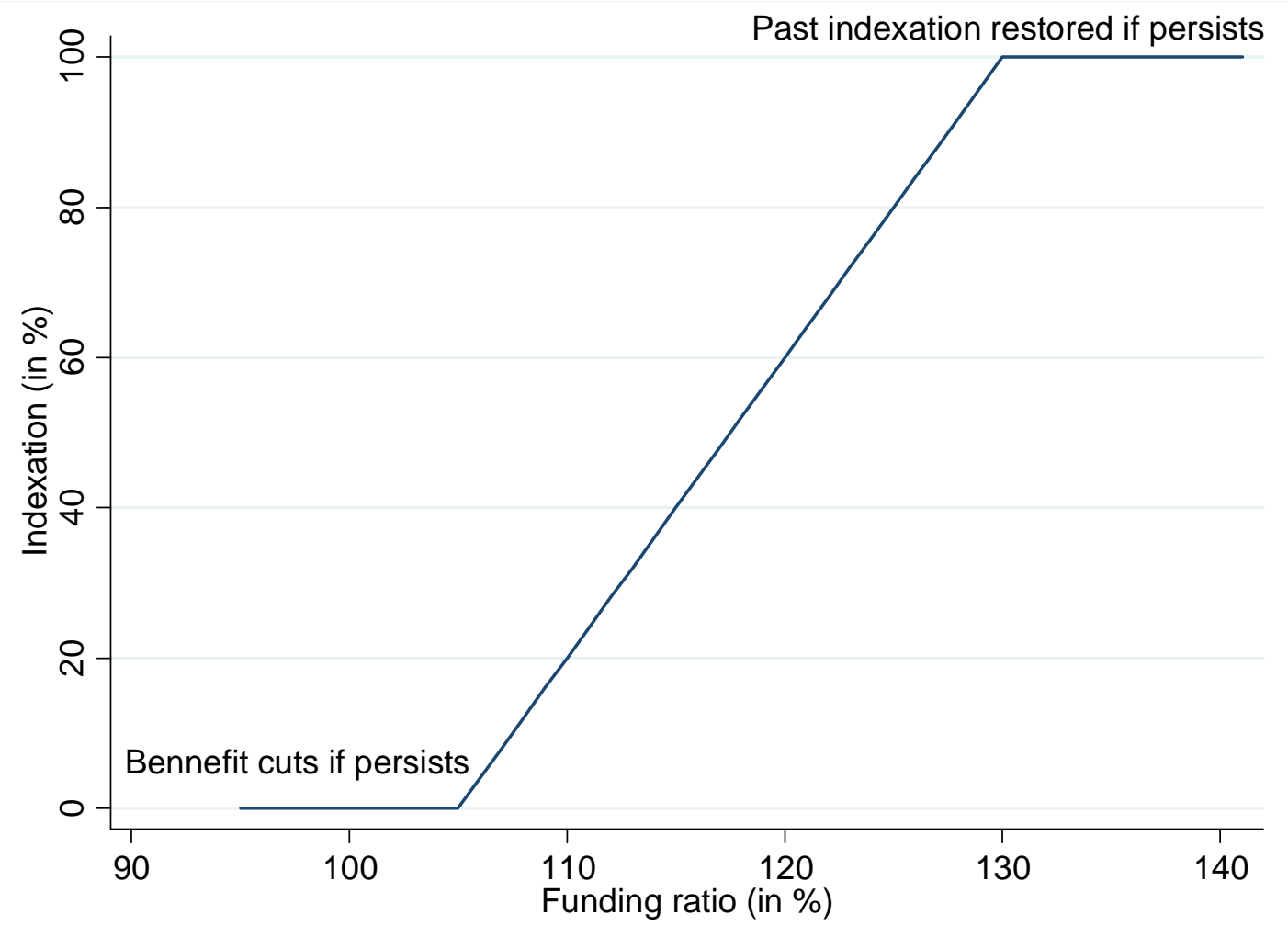


Figure 2: Distribution of pension fund risk for sample individuals and pension funds
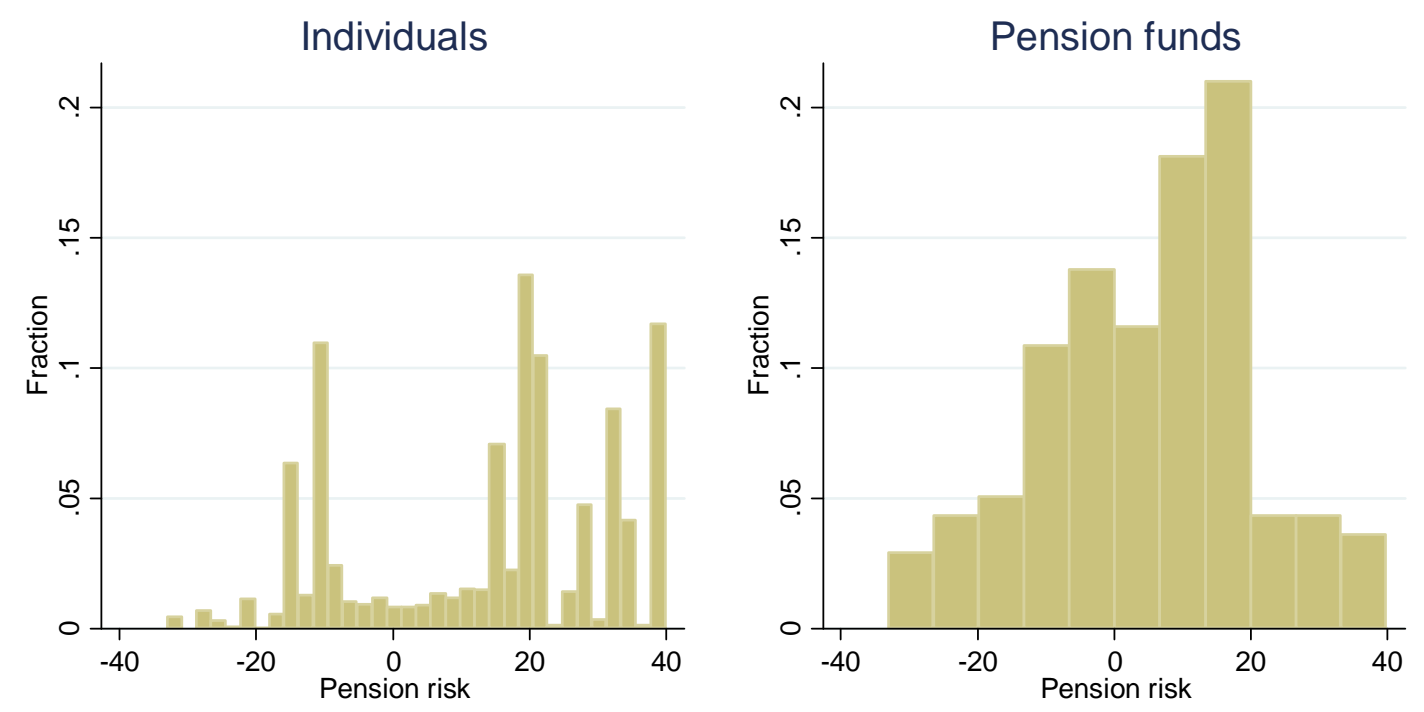
Figure 3: Evolution of pension risk over time and its variation after accounting for pension fund and year effects
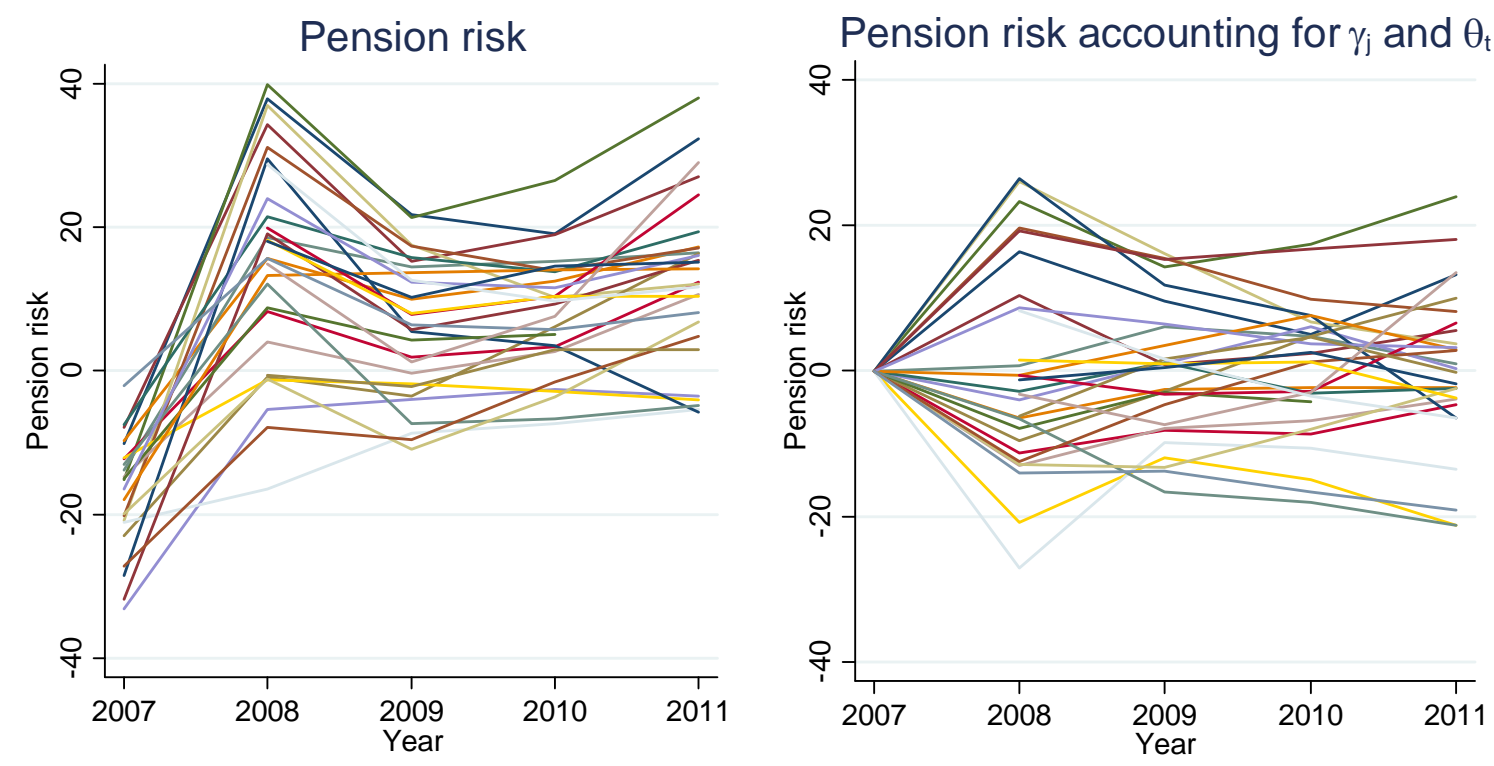


\section{Appendix}

Figure A1: Distributions of actual and required funding
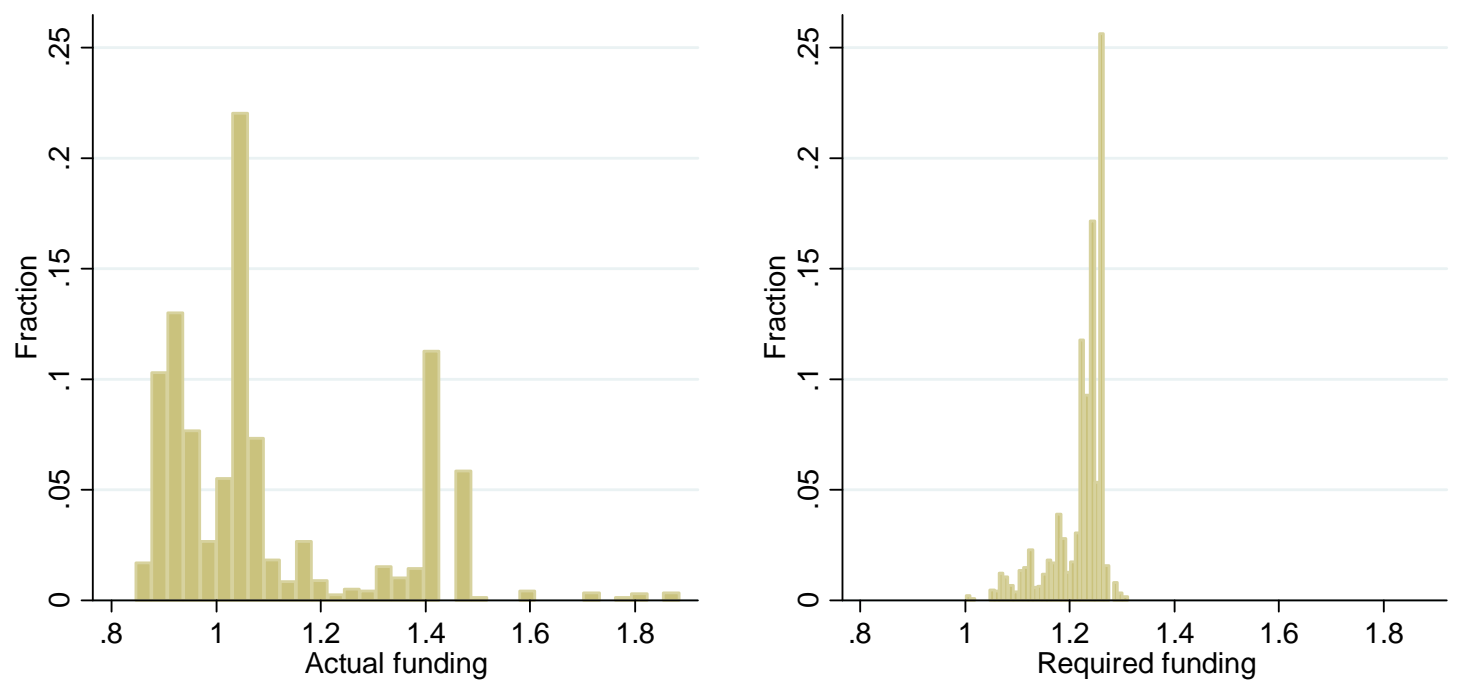
Table A1: Main effects of pension fund risk, controlling for pension fund asset allocation

\begin{tabular}{|c|c|c|c|c|}
\hline & \multicolumn{2}{|c|}{ Probit models } & \multicolumn{2}{|c|}{ Tobit models } \\
\hline & (1) & $(2)$ & (3) & (4) \\
\hline Dependent variable $=$ & $\begin{array}{l}\text { Holds } \\
\text { equity }\end{array}$ & $\begin{array}{l}\text { Plans to } \\
\text { retire early }\end{array}$ & Equity share & $\begin{array}{l}\text { Exp. } \\
\text { retirement } \\
\text { age }\end{array}$ \\
\hline Pension risk & $\begin{array}{l}-0.003 * \\
(0.002)\end{array}$ & $\begin{array}{c}-0.001 \\
(0.003)\end{array}$ & $\begin{array}{c}-0.176^{* *} \\
(0.081)\end{array}$ & $\begin{array}{c}0.021 \\
(0.062)\end{array}$ \\
\hline$P$. fund share in equity & $\begin{array}{l}-0.000 \\
(0.003)\end{array}$ & $\begin{array}{c}0.000 \\
(0.006)\end{array}$ & $\begin{array}{c}0.016 \\
(0.165)\end{array}$ & $\begin{array}{l}-0.020 \\
(0.098)\end{array}$ \\
\hline$P$. fund share in fixed income & $\begin{array}{l}-0.002 \\
(0.002)\end{array}$ & $\begin{array}{c}0.007 \\
(0.005)\end{array}$ & $\begin{array}{l}-0.095 \\
(0.136)\end{array}$ & $\begin{array}{c}0.057 \\
(0.066)\end{array}$ \\
\hline$P$. fund share in real estate & $\begin{array}{c}0.001 \\
(0.004)\end{array}$ & $\begin{array}{l}-0.000 \\
(0.008)\end{array}$ & $\begin{array}{c}-0.074 \\
(0.228)\end{array}$ & $\begin{array}{l}-0.155^{*} \\
(0.087)\end{array}$ \\
\hline$P$. fund share in other investments & $\begin{array}{l}-0.002 \\
(0.009)\end{array}$ & $\begin{array}{l}-0.023 \\
(0.015)\end{array}$ & $\begin{array}{l}-0.146 \\
(0.421)\end{array}$ & $\begin{array}{l}-0.146 \\
(0.367)\end{array}$ \\
\hline Other controls & Yes & Yes & Yes & Yes \\
\hline Year fixed effects & Yes & Yes & Yes & Yes \\
\hline Pension fund fixed effects & Yes & Yes & Yes & Yes \\
\hline Observations & 2,958 & 1,811 & 2,958 & 1,817 \\
\hline
\end{tabular}




\section{Table A2: Pension risk and funding and pension indexation beliefs}

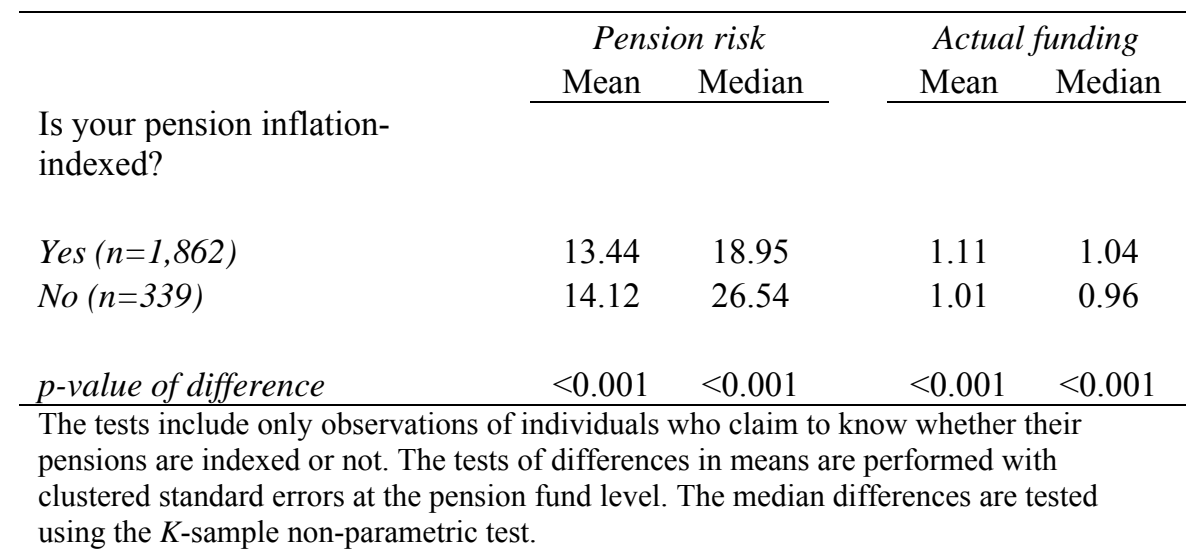


Table A3: Main effects of pension fund risk, controlling for current pension wealth

\begin{tabular}{|c|c|c|c|c|}
\hline & \multicolumn{2}{|c|}{ Probit models } & \multicolumn{2}{|c|}{ Tobit models } \\
\hline & (1) & (2) & (3) & (4) \\
\hline Dependent variable $=$ & $\begin{array}{l}\text { Holds } \\
\text { equity }\end{array}$ & $\begin{array}{l}\text { Plans to } \\
\text { retire early }\end{array}$ & $\begin{array}{l}\text { Equity } \\
\text { share }\end{array}$ & $\begin{array}{l}\text { Exp. } \\
\text { retirement } \\
\text { age }\end{array}$ \\
\hline Pension risk & $\begin{array}{c}-0.006 * * \\
(0.003)\end{array}$ & $\begin{array}{c}0.006 \\
(0.004)\end{array}$ & $\begin{array}{c}-0.279 * * * \\
(0.089)\end{array}$ & $\begin{array}{l}-0.114^{*} \\
(0.068)\end{array}$ \\
\hline Log hopusehold income if retiring now & $\begin{array}{c}0.013 * * * \\
(0.003)\end{array}$ & $\begin{array}{c}0.005 \\
(0.009)\end{array}$ & $\begin{array}{c}0.577 * * * \\
(0.159)\end{array}$ & $\begin{array}{c}-0.270 * * \\
(0.122)\end{array}$ \\
\hline Other controls & Yes & Yes & Yes & Yes \\
\hline Year fixed effects & Yes & Yes & Yes & Yes \\
\hline Pension fund fixed effects & Yes & Yes & Yes & Yes \\
\hline Observations & 1,345 & 866 & 1,373 & 879 \\
\hline
\end{tabular}


Table A4: Main effects of pension fund risk, controlling for housing wealth

\begin{tabular}{|c|c|c|c|c|}
\hline & \multicolumn{2}{|c|}{ Probit models } & \multicolumn{2}{|c|}{ Tobit models } \\
\hline & (1) & $(2)$ & (3) & (4) \\
\hline Dependent variable $=$ & $\begin{array}{l}\text { Holds } \\
\text { equity }\end{array}$ & $\begin{array}{c}\text { Plans to } \\
\text { retire } \\
\text { early }\end{array}$ & $\begin{array}{l}\text { Equity } \\
\text { share }\end{array}$ & $\begin{array}{l}\text { Exp. } \\
\text { retirement } \\
\text { age }\end{array}$ \\
\hline \multicolumn{5}{|l|}{ Without housing wealth: } \\
\hline \multirow[t]{2}{*}{ Pension risk } & -0.003 & 0.000 & -0.151 & -0.025 \\
\hline & $(0.002)$ & $(0.004)$ & $(0.093)$ & $(0.068)$ \\
\hline \multicolumn{5}{|l|}{ With housing wealth: } \\
\hline \multirow[t]{2}{*}{ Pension risk } & -0.003 & -0.000 & $-0.161 *$ & -0.018 \\
\hline & $(0.002)$ & $(0.004)$ & $(0.095)$ & $(0.067)$ \\
\hline \multirow[t]{2}{*}{ Log of house purchase value } & $0.069 * * *$ & $-0.075^{*}$ & $3.376 * * *$ & $1.258^{*}$ \\
\hline & $(0.022)$ & $(0.040)$ & $(1.141)$ & $(0.690)$ \\
\hline Other controls & Yes & Yes & Yes & Yes \\
\hline Year fixed effects & Yes & Yes & Yes & Yes \\
\hline Pension fund fixed effects & Yes & Yes & Yes & Yes \\
\hline Observations & 1,707 & 983 & 1,707 & 1,001 \\
\hline
\end{tabular}


Table A5: Transition probabilities of the pension fund and labor market status and pension risk before and after changes

\begin{tabular}{|c|c|c|c|c|c|c|}
\hline \multicolumn{7}{|c|}{ Pension fund transition $(n=1,412)$} \\
\hline & & $A$ & $B$ & & & \\
\hline$A$ & Remains in $P$. fund & 83.68 & 16.32 & & & \\
\hline$B$ & Changed $P$. fund & 78.08 & 21.92 & & & \\
\hline \multicolumn{7}{|c|}{ Employment transition $(n=1,412)$} \\
\hline & & 1 & 2 & 3 & 4 & 9 \\
\hline 1 & Employed & 97.03 & 0.13 & 0.26 & 2.33 & 0.26 \\
\hline 2 & Self-employed & 2.13 & 95.74 & 0 & 0 & 2.13 \\
\hline 3 & Unemployed & 20 & 0 & 70 & 10 & 0 \\
\hline 4 & Retired & 0 & 0 & 0.19 & 99.81 & 0 \\
\hline 9 & Other & 1.67 & 1.67 & 0 & 1.67 & 95 \\
\hline \multicolumn{7}{|c|}{ Before and after pension fund change } \\
\hline & & $\begin{array}{c}\text { Year } \\
\text { before } \\
\text { changing }\end{array}$ & $\begin{array}{c}\text { Year } \\
\text { after } \\
\text { change }\end{array}$ & & & \\
\hline \multicolumn{7}{|c|}{ Mean of: } \\
\hline & Pension risk & 10.73 & 15.04 & & & \\
\hline & Actual funding & 1.13 & 1.07 & & & \\
\hline
\end{tabular}




\section{Table A6: Main effects of pension risk under alternative specifications}

\begin{tabular}{|c|c|c|c|c|}
\hline \multirow{3}{*}{ Dependent variable $=$} & \multicolumn{2}{|c|}{ Probit models } & \multicolumn{2}{|c|}{ Tobit models } \\
\hline & (1) & $(2)$ & (3) & (4) \\
\hline & $\begin{array}{l}\text { Holds } \\
\text { equity }\end{array}$ & $\begin{array}{l}\text { Plans to } \\
\text { retire early }\end{array}$ & $\begin{array}{l}\text { Equity } \\
\text { share }\end{array}$ & $\begin{array}{l}\text { Exp. } \\
\text { retirement } \\
\text { age }\end{array}$ \\
\hline \multirow{2}{*}{$\begin{array}{l}\text { Specification: } \\
\text { a) Inverse probability weighting }\end{array}$} & \multicolumn{4}{|c|}{ The marginal effect of pension risk: } \\
\hline & $\begin{array}{c}-0.003 * * \\
(0.001)\end{array}$ & $\begin{array}{c}0.000 \\
(0.001)\end{array}$ & $\begin{array}{c}-0.169 * * \\
(0.069)\end{array}$ & $\begin{array}{l}-0.006 \\
(0.131)\end{array}$ \\
\hline Observations & 2,924 & 1,799 & 2,938 & 1,806 \\
\hline b) Heteroskedastic models & $\begin{array}{c}-0.003 * * \\
(0.001)\end{array}$ & $\begin{array}{l}-0.000 \\
(0.001)\end{array}$ & $\begin{array}{l}- \\
-\end{array}$ & $\begin{array}{l}- \\
-\end{array}$ \\
\hline Observations & 2,958 & 1,811 & - & - \\
\hline c) Lag in pension risk & $\begin{array}{c}-0.003 * * * \\
(0.001)\end{array}$ & $\begin{array}{l}-0.001 \\
(0.003)\end{array}$ & $\begin{array}{c}-0.154 * * * \\
(0.057)\end{array}$ & $\begin{array}{c}0.039 \\
(0.047)\end{array}$ \\
\hline Observations & 1,795 & 1,069 & 1,833 & 1,076 \\
\hline d) No control variables & $\begin{array}{l}-0.003 * \\
(0.002)\end{array}$ & $\begin{array}{l}-0.001 \\
(0.003)\end{array}$ & $\begin{array}{l}-0.151 * \\
(0.083)\end{array}$ & $\begin{array}{c}0.057 \\
(0.057)\end{array}$ \\
\hline Observations & 2,958 & 1,673 & 2,958 & 1,678 \\
\hline e) No largest pension fund & $\begin{array}{c}-0.004 * * * \\
(0.002)\end{array}$ & $\begin{array}{c}0.001 \\
(0.003)\end{array}$ & $\begin{array}{c}-0.229 * * * \\
(0.065)\end{array}$ & $\begin{array}{c}0.042 \\
(0.059)\end{array}$ \\
\hline Observations & 1,678 & 1,125 & 1,699 & 1,131 \\
\hline f) No fixed effects & $\begin{array}{c}-0.001 * * \\
(0.001)\end{array}$ & $\begin{array}{c}-0.002^{* * * *} \\
(0.001)\end{array}$ & $\begin{array}{c}-0.076^{* * *} \\
(0.026)\end{array}$ & $\begin{array}{c}0.007 \\
(0.015)\end{array}$ \\
\hline Observations & 2,958 & 1,678 & 2,958 & 1,678 \\
\hline g) Individual means & $\begin{array}{c}-0.002 * * * \\
(0.001)\end{array}$ & $\begin{array}{l}-0.001 \\
(0.001)\end{array}$ & $\begin{array}{c}-0.092 * * * \\
(0.026)\end{array}$ & $\begin{array}{c}0.002 \\
(0.013)\end{array}$ \\
\hline Observations & 1,696 & 1,075 & 1,699 & 1,081 \\
\hline \multicolumn{5}{|c|}{$\begin{array}{l}\text { a) The variables in the first-stage probit regression (z) include gender, age, times reported wealth in } \\
\text { sample, times reported unemployed in sample, times changed occupation in sample, detailed education, } \\
\text { detailed occupation, marital status, household members, main earner, and year fixed effects. } \\
\text { b) All the regressors, except pension fund and year fixed effects, are used to predict the variance of the } \\
\text { error term. } \\
\text { d) These regressions include only year and pension fund fixed effects. }\end{array}$} \\
\hline \multirow{2}{*}{\multicolumn{5}{|c|}{$\begin{array}{l}\text { e) These regressions exclude the largest pension fund ( } 42 \% \text { of our main sample) from the estimation. } \\
\text { f) These regressions include only the control variables reported in Table } 2 \text {. }\end{array}$}} \\
\hline & & & & \\
\hline \multicolumn{5}{|c|}{$\begin{array}{l}\text { e) These regressions are on collapsed data by individual and include median pension fund fixed effects. } \\
\text { Standard errors clustered at the pension fund level are in parentheses. } * * * p<0.01, * * p<0.05, * p< \\
0.1 \text {. All columns report average marginal effects. }\end{array}$} \\
\hline
\end{tabular}

